Jurnal Ilmu-Ilmu Peternakan 26 (2): 67 - 72

ISSN : 0852-3681

E-ISSN : 2443-0765

CFakultas Peternakan UB, http://jiip.ub.ac.id/

\title{
Complete feed batang pisang terfermentasi dengan level protein berbeda terhadap kecernaan bahan kering, kecernaan bahan organik dan TDN secara in vitro
}

\author{
Nurita Thiasari dan Ahmad Iskandar Setiyawan \\ Universitas Tribhuwana Tunggadewi \\ Jl. Telaga Warna Blok C \\ nurita.unitri15@gmail.com
}

\begin{abstract}
The study aimed to investigate the effect of protein level in the complete feed based on fermented banana pseudostem(CFFBP) on in vitro digestibility. The experiment was conducted from May to August 2016. CFFBP was made at the field laboratory of Tribhuwana Tunggadewi University, Malang. Proximate and in vitro digestibility analysis was carried out at the Animal Nutrition Laboratory, the Faculty of Animal Husbandry, Brawijaya University. The experiment used Completely Randomized Design with 3 treatments and 5 replications. The treatments were $\mathrm{P}_{1} \mathrm{CFFBP}$ at protein level $12 \%$; $\mathrm{P}_{2}$ CFFBP at protein level 14\%; $\mathrm{P}_{3}$ CFFBP at protein level $16 \%$. The results showed that digestibility of dry matter (DMD), digestibility of organic matter (OMD) and Total Digestible Nutrient (TDN) were significantly affected by the treatments $(\mathrm{P}<0.01)$. The highest digestibility of DMD, of OMD and TDN was found at CFFBP with protein level 14\%. The DMD value were $\mathrm{P}_{1} 71.56 \%, \mathrm{P}_{2} 75.06 \%$ and $\mathrm{P}_{3}$ $74.32 \%$. The OMD value were $\mathrm{P}_{1} 65.53 \%, \mathrm{P}_{2} 68.50 \%$ and $\mathrm{P}_{3} 69,82 \%$. The TDN value were $\mathrm{P}_{1} 61.84 \%, \mathrm{P}_{2} 66.07 \%$ and $\mathrm{P}_{3} 64.91 \%$. The experiment concluded that the increasing level of protein in the CFFBP could increase DMD, OMD and TDN, and it was related to the availability of protein and energy ratio. The ideal level of protein in this experiment was $14 \%$.
\end{abstract}

Keywords: complete feed, fermented banana pseudostem, in vivo digestibility, protein level

\section{PENDAHULUAN}

Di Indonesia banyak dijumpai tanaman pisang yang memiliki sifat mudah tumbuh tanpa pupuk dan pestisida. Tanaman pisang hanya dapat dipanen satu kali dan dimanfaatkan buah, daun dan bunga sedangkan bagian batangnya harus dipotong agar tidak mengganggu pertumbuhan tanaman pisang yang lain. Hal ini menyebabkan ketersediaan batang pisang melimpah sehingga potensial sebagai pakan ternak. Menurut Pusat Data dan Sistem Informasi Pertanian Sekretariat Jenderal Kementerian Pertanian (2014), produksi pisang di Indonesia mencapai 6,28 juta ton pada tahun 2013. Ffoulkes et al. (1977) menyatakan bahwa perbandingan buah pisang, daun dan batang berdasarkan bahan kering berturut-turut adalah 37\%, 25\% dan $39 \%$. Berdasarkan perbandingan tersebut dapat diperoleh batang pisang 
dalam bahan kering sebanyak 6,62 juta ton pada tahun yang sama.

Kondisi batang pisang yang mudah rusak serta kualitas nutrisi yang rendah merupakan kendala yang dihadapi peternak dalam memanfaatkan batang pisang dalam bentuk segar sebagai pakan ternak. Menurut Poyyamozhi and Kardivel (1986), batang pisang mengandung nutrisi antara lain Bahan Kering (BK) 9,8\%, Total Abu18,4\%, Lemak Kasar (LK) 3,2\%, Serat Kasar (SK) 31,7\%, dan Protein Kasar (PK) 8,8\%. Pakan ternak yang bersumber dari limbah pertanian dan perkebunan memiliki nilai nutrisi rendah sehingga perlu dioptimalkan kualitasnya melalui teknologi fermentasi dan pembuatan pakan lengkap (complete feed) (Wahyono dan Hardianto, 2004).

Pada proses fermentasi terjadi peningkatan daya cerna dan nilai protein pakan akibat dari pemanfaatan nitrogen inorganik menjadi protein sel mikroorganisme (Purwadaria, 1998). Disamping itu, fermentasi juga merupakan metode pengawetan limbah pertanian secara biologis oleh produk hasil fermentasi berupa asam organik (Utama dan Mulyanto, 2009).

Pada masa ini banyak dikembangkan pembuatan complete feed dengan bahan basal limbah pertanian salah satunya batang pisang. Complete feed adalah metode pemberian pakan dengan mencampurkan hijauan dan konsentrat secara homogen yang bertujuan untuk meningkatkan nilai nutrisi pakan, palatabilitas serta mencegah ternak menseleksi pakan. Pemberian pakan dalam bentuk complete feed dapat meningkatkan konsumsi pakan dan pertambahan bobot badan harian sapi potong (Nusi, dkk, 2011).

Pemberian complete feed diharapkan dapat mencukupi kebutuhan protein ternak yang erat kaitannya dengan produksi ternak. Pada pakan domba penggemukan dibutuhkan protein kasar (PK) sebesar 12-14\% (Stanton and Levalley, 2004). Haryanto dan Djajanegara merekomendasikan PK dalam pakan domba penggemukan adalah 14-15\%. Berdasarkan uraian diatas, penelitian mengenai complete feed berbasis batang pisang terfermentasi dengan level protein kasar yang berbeda terhadap Kecernaan Bahan Kering (KBK), Kecernaan Bahan Organik (KBO) dan TDN (Total Digestible Nutrient) perlu diperlukan.

\section{MATERI DAN METODE}

Pembuatan batang pisang terfermentasi sampai menjadi complete feed dilaksanakan pada bulan Mei hingga Agustus 2016 di Universitas Tribhuwana Tunggadewi. Analisis proksimat dan kecernaan in vitro dilaksanakan di Laboratorium Nutrisi dan Makanan Ternak, Fakultas Peternakan, Universitas Brawijaya.

Materi yang digunakan adalah Complete feed dengan perbandingan batang pisang terfermentasi dan konsentrat sebesar 50:50. Cara pembuatan batang pisang terfermentasi yaitu batang pisang yang telah dipotong (3-4 cm) ditambahkan dedak padi 10\% dan EM4 kemudian difermentasikan selama 21 hari. Kemudian batang pisang terfermentasi dicampur dengan konsentrat. Bahan penyusun konsentrat berupa jagung, pollard, bungkil kedelai dan garam. Kandungan nutrien bahan pakan penyusun complete feed disajikan pada Tabel 1. Berdasarkan data kandungan nutrien tersebut kemudian dihitung proporsi dan kandungan nutrien bahan pakan penyusun complete feed sesuai dengan perlakuan yang dapat dilihat pada Tabel 2 dan Tabel 3. 
Tabel 1. Kandungan nutrien bahan-bahan pakan penyusun complete feed

\begin{tabular}{lccccc}
\hline \multirow{2}{*}{ Bahan pakan } & \multirow{2}{*}{ BK (\%) } & \multicolumn{4}{c}{ Kandungan nutrien (\% BK) } \\
\cline { 2 - 6 } & & BO & PK & SK & LK \\
\hline Batang pisang terfermentasi & 12,01 & 82,23 & 4,46 & 35,02 & 3,22 \\
Bungkil kedelai & 87,26 & 91,15 & 44,33 & 7,78 & 1,22 \\
Pollard & 90,04 & 94,36 & 16,49 & 6,42 & 14,42 \\
Jagung & 87,88 & 95,81 & 9,22 & 2,90 & 4,58 \\
Garam & 95,44 & 7,24 & - & - & - \\
\hline
\end{tabular}

Tabel 2. Proporsi bahan pakan penyusun complete feed batang pisang terfermentasi

\begin{tabular}{lccc}
\hline \multirow{2}{*}{ Bahan pakan } & \multicolumn{3}{c}{ Perlakuan } \\
\cline { 2 - 4 } & $\mathrm{P}_{1}$ & $\mathrm{P}_{2}$ & $\mathrm{P}_{3}$ \\
\hline Batang pisang terfermentasi & 50 & 50 & 50 \\
Bungkil kedelai (\%) & 12,5 & 17 & 22,5 \\
Pollard (\%) & 12 & 18 & 19,5 \\
Jagung (\%) & 24,5 & 14 & 7 \\
Garam (\%) & 1 & 1 & 1 \\
\hline \multicolumn{1}{c}{ Total } & 100 & 100 & 100 \\
\hline
\end{tabular}

Tabel 3. Kandungan nutrien complete feed batang pisang terfermentasi hasil perhitungan berdasarkan Tabel 1 dan Tabel 2.

\begin{tabular}{lccc}
\hline \multirow{2}{*}{ Kandungan nutrien } & \multicolumn{3}{c}{ Perlakuan } \\
\cline { 2 - 4 } & $\mathrm{P}_{1}$ & $\mathrm{P}_{2}$ & $\mathrm{P}_{3}$ \\
\hline BK (\%) & 49,25 & 50,30 & 50,30 \\
BO (\% BK) & 87,30 & 87,08 & 86,80 \\
PK (\% BK) & 12,01 & 14,02 & 16,06 \\
SK (\% BK) & 19,96 & 20,39 & 20,71 \\
LK (\% BK) & 4,61 & 5,05 & 5,02 \\
\hline
\end{tabular}

Metode yang digunakan dalam penelitian ini adalah metode percobaan. Rancangan yang digunakan dalam penelitian ini adalah Rancangan Acak Lengkap (RAL) dengan 3 perlakuan dan 5 kali ulangan. Pakan perlakuan berupa complete feed batang pisang terfermentasi dengan level protein yang berbeda. Adapun perlakuan dalam penelitian ini adalah sebagai berikut :

$\mathrm{P}_{1}=$ Complete feed batang pisang terfermentasi PK 12\%

$\mathrm{P}_{2}=$ Complete feed batang pisang terfermentasi PK 14\%

$\mathrm{P}_{3}=$ Complete feed batang pisang terfermentasi PK 16\%

Penelitian ini melakukan pengujian kecernaan secara in vitro menggunakan metode Tilley and Terry (1963). KBK, KBO dan TDN dihitung dengan menggunakan rumus :

$$
\begin{gathered}
\mathrm{KBK}=\frac{\mathrm{BK} \text { awal-(BK residu-BK blanko) }}{\mathrm{BK} \text { awal }} \times 100 \% \\
\mathrm{KBO}=\frac{\mathrm{BO} \text { awal-(BO residu-BO blanko) }}{\mathrm{BO} \text { awal }} \times 100 \% \\
\mathrm{TDN}=\frac{\mathrm{BO} \text { awal } \mathrm{x} \text { DBO }}{100} \times 1,05
\end{gathered}
$$

Variabel yang diamati dalam penelitian ini adalah KBK, KBO dan TDN. Data yang diperoleh kemudian dianalisis menggunakan analisis ragam (ANOVA). Apabila terdapat perbedaan dalam perlakuan maka dilakukan Uji 
Beda Nyata Terkecil (BNT) (Steel and Torrie, 1980).

\section{HASIL DAN PEMBAHASAN}

Pakan perlakuan dalam penelitian ini dalam bentuk complete feed yang merupakan campuran beberapa bahan pakan guna memenuhi kebutuhan nutrien ternak (Fuller, 2004). Tabel 4 menunjukkan bahwa batang pisang terfermentasi dalam bentuk complete feed memiliki KBK dan KBO yang lebih tinggi dibandingkan dengan batang pisang terfermentasi sebagai pakan tunggal. Menurut Santi, dkk
(2012), KBK dan KBO batang pisang terfermentasi memiliki berturut-turut adalah 39,34\% dan 40,87. McDonald et.al (2011) menyebutkan bahwa nilai kecernaan satu jenis bahan pakan dapat ditingkatkan dengan mengkombinasikan beberapa bahan pakan dalam bentuk complete feed. Penggunaan bahan pakan tinggi protein dalam complete feed dapat meningkatkan nilai kecernaan karena protein meningkatkan aktifitas mikroorganisme sehingga membantu dalam mencerna pakan.

Tabel 4. Rata-rata KBK, KBO dan TDN pakan perlakuan

\begin{tabular}{lccc}
\hline \multirow{2}{*}{ Parameter } & \multicolumn{3}{c}{ Perlakuan } \\
\cline { 2 - 4 } & $\mathrm{P}_{1}$ & $\mathrm{P}_{2}$ & $\mathrm{P}_{3}$ \\
\hline KBK (\%) & $71,56^{\mathrm{a}}$ & $75,06^{\mathrm{b}}$ & $74,32^{\mathrm{b}}$ \\
KBO (\%) & $65,53^{\mathrm{a}}$ & $68,50^{\mathrm{b}}$ & $69,82^{\mathrm{b}}$ \\
TDN (\%) & $61,84^{\mathrm{a}}$ & $66,07^{\mathrm{b}}$ & $64,91^{\mathrm{b}}$
\end{tabular}

Keterangan: ${ }^{\mathrm{a}-\mathrm{b}}$ superskrip yang berbeda pada kolom yang sama menunjukkan perbedaan yang sangat nyata $(\mathrm{P}<0,01)$

Tabel 4 menunjukkan bahwa perlakuan pakan complete feed batang pisang terfermentasi pada level protein yang berbeda memberikan pengaruh yang sangat nyata $(\mathrm{P}<0,01)$ terhadap KBK. Apabila dibandingkan nilai KBK pakan perlakuan $\mathrm{P}_{1}$ (PK 12\%) dengan $\mathrm{P}_{2}$ (PK 14\%) dan $\mathrm{P}_{3}$ (PK 16\%), maka meningkatnya level protein pada pakan perlakuan mengakibatkan peningkatan nilai KBK. Hal ini sesuai dengan pernyataan Sultan et al. (2010) yang menyatakan bahwa kecernaan berhubungan dengan komposisi kimia pakan yaitu protein dimana KBK meningkat secara linier dengan peningkatan level protein dalam pakan. Hasil penelitian nilai KBK yang sama pada $\mathrm{P}_{2}$ (PK 14\%) dan $\mathrm{P}_{3}$ (PK 16\%) dapat disebabkan oleh ketidakseimbangan protein dan energi dalam pakan, sehingga dengan meningkatnya level protein tidak diikuti peningkatan nilai KBK.

Kaswari (2004) menyatakan bahwa mikroorganisme dalam rumen berperan dalam proses pencernaan pakan pada ternak ruminansia. Pertumbuhan mikroorganisme dalam rumen utamanya dipengaruhi oleh ketersediaan protein dan energi dalam pakan. Kekurangan protein maupun energi dalam pakan menyebabkan pertumbuhan mikroorganisme tidak optimal dan mengurangi kecernaan pakan.

Peningkatan level protein dalam pakan meningkatkan nilai KBO $(\mathrm{P}<0,01)$. Tabel 4 juga menunjukkan bahwa rataan nilai $\mathrm{KBO}$ mengindikasikan hasil yang sama dengan rataan $\mathrm{KBK}$, yaitu semakin tinggi level protein menyebabkan peningkatan KBO. Hal ini didukung oleh pernyataan Wilkins dan Grimes 
(1966) bahwa KBK memiliki korelasi positif terhadap KBO. Wahyuni, dkk. (2014) menambahkan bahwa KBK erat kaitannya dengan $\mathrm{KBO}$, karena bahan organik merupakan komponen dari bahan kering. Peningkatan KBK akan mengakibatkan $\mathrm{KBO}$ meningkat atau sebaliknya.

TDN merupakan gabungan dari kecernaan komponen serat, protein, lemak dan karbohidrat dalam pakan (Van Soest, 1994). Hasil analisis ragam menunjukkan adalanya perbedaan yang sangat nyata terhadap nilai TDN pakan perlakuan $(\mathrm{P}<0,01)$. Hasil penelitian mencerminkan bahwa peningkatan level protein dalam pakan meningkatkan kecernaan serat, protein, lemak dan karbohidrat.

\section{KESIMPULAN}

Berdasarkan hasil penelitian dapat disimpulkan bahwa semakin tinggi level protein dalam complete feed berbasis batang pisang fermentasi menyebabkan KBK, KBO dan TDN meningkat namun dibatasi oleh rasio protein dan energi dalam pakan. PK ideal untuk Complete feed berbasis batang pisang terfermentasi adalah $14 \%$.

\section{DAFTAR PUSTAKA}

Ffoulkes, D. S. Espejo, D. Marie, M. Delpeche and T. R. Preston. 1977. The banana plant as cattle feed: Composition and biomass production. Trop. Anim. Prod. 3(1): 45-50.

Fuller, M. F. 2004. The encyclopedia of farm animal nutrition. CABI Publishing. United Kingdom.

Haryanto, B. dan A. Djajanegara. 1993. Pemenuhan kebutuhan zat-zat makanan ternak ruminansia kecil. Dalam: Produksi kambing dan domba di Indonesia. Sebelas
Maret University Press. Surakarta.

Kaswari, T. 2004. Synchronization of energy and protein supply in the rumen of dairy cows. Cuvillier Verlag Gottingen. Braunschweig.

McDonald, P., R. A. Edwards and J. F. O. Greenhalgh. 2011. Animal nutrition. Seventh Edition. Longman Scientific and Technical. New York.

Nusi, M., R.Utomo dan Soeparno. 2011. Pengaruh penggunaan tongkol jagung dalam complete feed dan suplementasi undegraded protein terhadap pertambahan bobot badan dan kualitas daging pada Sapi Peranakan Ongole. Buletin Peternakan Vol. 35(3): 1-9.

Poyyamozhi, V. S. and Kardivel, R. 1986. The nutritive of banana stalk as a feed for goats. Anim. Feed Sci. Tech. 15:95-100.

Purwadaria, T. 1998. Strategi peningkatan kualitas pakan ternak monogastrik dalam inovasi teknologi pertanian: Seperempat abad penelitian dan pengembangan pertanian, Volume 2. Departemen Pertanian, Badan Penelitian dan Pengembangan Pertanian. Jakarta.

Pusat Data dan Sistem Informasi Pertanian Sekretariat Jenderal Kementerian Pertanian. 2014. Outlook komoditas pisang. Pusat data dan sistem pertanian. Jakarta. Diakses tanggal 3 Maret 2016.

http://epublikasi.setjen.pertanian .go.id/arsip-outlook/76-outlookhortikultura/300-outlookkomoditas-pisang-2014.

Santi, R. K., D. Fatmasari, S. D. Widyawati dan W. P. S. 
Suprayogi. 2012. Kualitas dan nilai kecernaan in vitro silase batang pisang (Musa parasidiaca) dengan penambahan beberapa akselerator. Tropical Animal Husbandry Vol. 1 (1), Oktober 2012:15-23

Stanton T. L. and B. Levalley. 2004. Lamb feedlot nutrition. CSU Cooperative ExtensionAgriculture. Colorado State University Cooperative Extension, Colorado. pp. $1-8$.

Steel, R. G. D. and J. H. Torrie. 1980. Principles and procedure of statistics. 2nd Ed. Mc. Graw Hill International Book Co. Singapore.

Sultan, J. I., A. Javaid and M. Aslam. 2010. Nutrient digestibility and feedlot performance of lambs fed diets varying protein and energy contents. Tropical Animal Health and Production. Vol. 42(5): 941-946

Tilley, J. M. A. and Terry, R. A. 1963. A two stage technique for the in vitro digestion of forage.J.
British Grassland Soc. 18:104111.

Utama, C. S. dan A. Mulyanto. 2009. Potensi limbah pasar sayur menjadi starter fermentasi. Jurnal Kesehatan Vol. 2(1): 613.

Van Soest, P. J. 1994. Nutritional ecology of the ruminant $2^{\text {nd }} \mathrm{Ed}$. Cornell University Press, Ithaca. Ney York Hal. 247-248.

Wahyono, D. Eko dan R. Hardianto. 2004. Pemanfaatan sumberdaya pakan lokal untuk pengembangan usaha sapi potong. Lokakarya Nasional Sapi Potong. 66-76.

Wahyuni, I. M. D, A. Muktiani dan M. Christiyanto. 2014. Kecernaan bahan kering dan bahan organik dan degradabilitas serat pada pakan yang disuplementasi tanin dan saponin. Agripet, 2 (2) : 115-124.

Wilkins, R. J., and R. C. Grimes. 1966. Herbage digestibility in sheep and corresponding estimates of digestibility in vitro. Proc. Aust. Sot. Anim. Prod. 6:334-339. 